\title{
Contagion across Eurozone's sovereign spreads and the Core-Periphery divide
}

\author{
Elisabetta Croci Angelini \\ University of Macerata
}

\author{
Francesco Farina* \\ University of Siena
}

Enzo Valentini

University of Macerata

\begin{abstract}
This paper investigates the causes of the disproportionate increases of sovereign yields with respect to the interest rate on the 10 years German Bund within the Eurozone. Empirical evidence drawn from banks' portfolios shows that rapid financial integration following the launch of the monetary union resulted in excess exposure of Core countries' banks in the Peripheral countries' financial assets, which exposed the network of highly interconnected European banks to a systemic risk. Data show that after the outbreak of the financial crisis the Core banks' portfolio diversification towards the Periphery was reversed by the "flight to quality". Estimates conducted by our GVAR model, where each country's spread depends upon all Eurozone countries' spreads, indicate that the rise in the Core countries' spreads was initially determined by the rising international risk aversion, whereas the huge rise in the sovereign yields of Peripheral countries is correlated to their macroeconomic fundamentals, namely the public debt / GDP ratio and REER values increasing with respect to the Eurozone average index. Our results also validate the hypothesis that a contagion developed from the Periphery's to the Core countries' interest rate differentials vis-à-vis Germany. The rise of the Core spreads has to be traced back to mounting expectations in the markets of an enduring financial instability within the Eurozone, associated with possible defaults in the Periphery.
\end{abstract}

\footnotetext{
${ }^{*}$ Corresponding author: francesco.farina@unisi.it
} 
Keywords: Sovereign bond spreads; monetary union; international risk aversion.

JEL Classification: E42; F36, F42, G12, H63.

\section{Introduction}

After the adoption of the euro and the end of the exchange rate risk, a rapid financial integration process developed in Europe, even more impressive than the 1990s unprecedented jump in worldwide capital movements. We provide evidence that a huge portfolio diversification was operated by highly interconnected banks, mainly consisting of large positions taken by the banks of the Core $^{1}$ countries in the sovereign bonds of the Peripheral ${ }^{2}$ countries.

The balance between pros and cons of diversification is difficult to assess (Greenwald and Stiglitz, 1986; Stiglitz, 2010) ${ }^{3}$. On the one hand, portfolio diversification puts forward the fractionalisation of risk across a larger number of investors, which favours the shrinking of the default risk premium on sovereign bonds. On the other hand, excessive interconnectivity across financial institutions can make markets more volatile. The risk of a systemic crisis can then materialize among the countries involved in a financial integration. The more the portfolios had been diversified through cross-border operations, the higher the risk that a large shock could develop a contagion across the yields of Eurozone countries' sovereign bonds.

This paper investigates the causes of the varying distance between the interest rate on the 10-year bonds of Eurozone countries and the interest rate on the German 10-year Bund. The econometric model takes account of the huge increase in cross-border investments which after the launch of the euro magnified the interconnectivity across European banks, resulting in excess exposure of Core countries' banks in the Peripheral countries' financial assets. A perverse interaction developed during the financial crisis between the expected returns of the banks turning negative and the heterogeneous degree of riskiness

\footnotetext{
${ }^{1}$ Austria, Belgium, Finland, France, German and the Netherland.

${ }^{2}$ Greece, Ireland, Italy, Portugal and Spain.

3 "Whether greater interconnectivity is net positive or negative thus depends on whether the first set of effects, the diversification benefits, outweighs the second, the contagion costs. That depends both on the degree of risk aversion, the concavity of production functions (the extent to which they exhibit diminishing returns), the costs of bankruptcy, and the impact of sharing on the probability of bankruptcy." (Stiglitz, 2010, p.24)
} 
of the stock of public debt issued by the countries of the currency area. Due to the increase in international risk aversion and the worsening of macroeconomic conditions in the Periphery, the sovereign bond yields of the these countries soared and the declining credibility of the Eurozone caused also the Core countries to be contaged.

In section 2, we review the relevant literature on financial integration within the Eurozone, and provide empirical evidence on both the evolution of the market sentiment and of the sovereign bond spreads from the inception of the monetary union up to year 2012. In section 3, by constructing a GVAR model where each country's spread depends upon all Eurozone countries' spreads, we test to what extent the international risk aversion interacted with worsening macroeconomic fundamentals in the propagation of a contagion effect across the Core's and the Periphery's sovereign spreads. Section 4 presents our econometric results. Section 5 concludes.

\section{Main facts and literature review}

The completion of the monetary union with the adoption of the euro accelerated integration across the EMU credit and capital markets (Jappelli and Pagano, 2010). The end of the exchange rate risk and a lowering international risk aversion were nourishing positive expectations about the future of the Eurozone. As shown in Figure 1, all sovereign spreads of the Eurozone, considering nil the interest rate on the virtually risk-free German Bund functioning as the benchmark, exhibited a fall. From the inception of the monetary union to the financial crisis, the portfolios of European banks experienced a profound reshuffling. Within the cross-border positions in assets and liabilities of many banks of the Core countries, the sovereign bonds of Peripheral countries disproportionately increased.

The mounting expectation of higher rates of return to be gained in countries with relatively scarcer capital and lower per capita GDP was a likely driver of the cross-country diversification process (Waysand et al., 2010; Schmitz and von Hagen, 2011). As a consequence, between January 1999 and August 2007, the average sovereign yield spreads of the Peripheral countries against Germany was never larger than 15 basis points. Countries with high public debt relative to GDP were more heavily penalised (Codogno et al., 2003; Lane and MilesiFerretti, 2008; Balli et al., 2010). Table 1 documents the portfolio 
Figure 1: Spreads path, 2000q1-2012q4

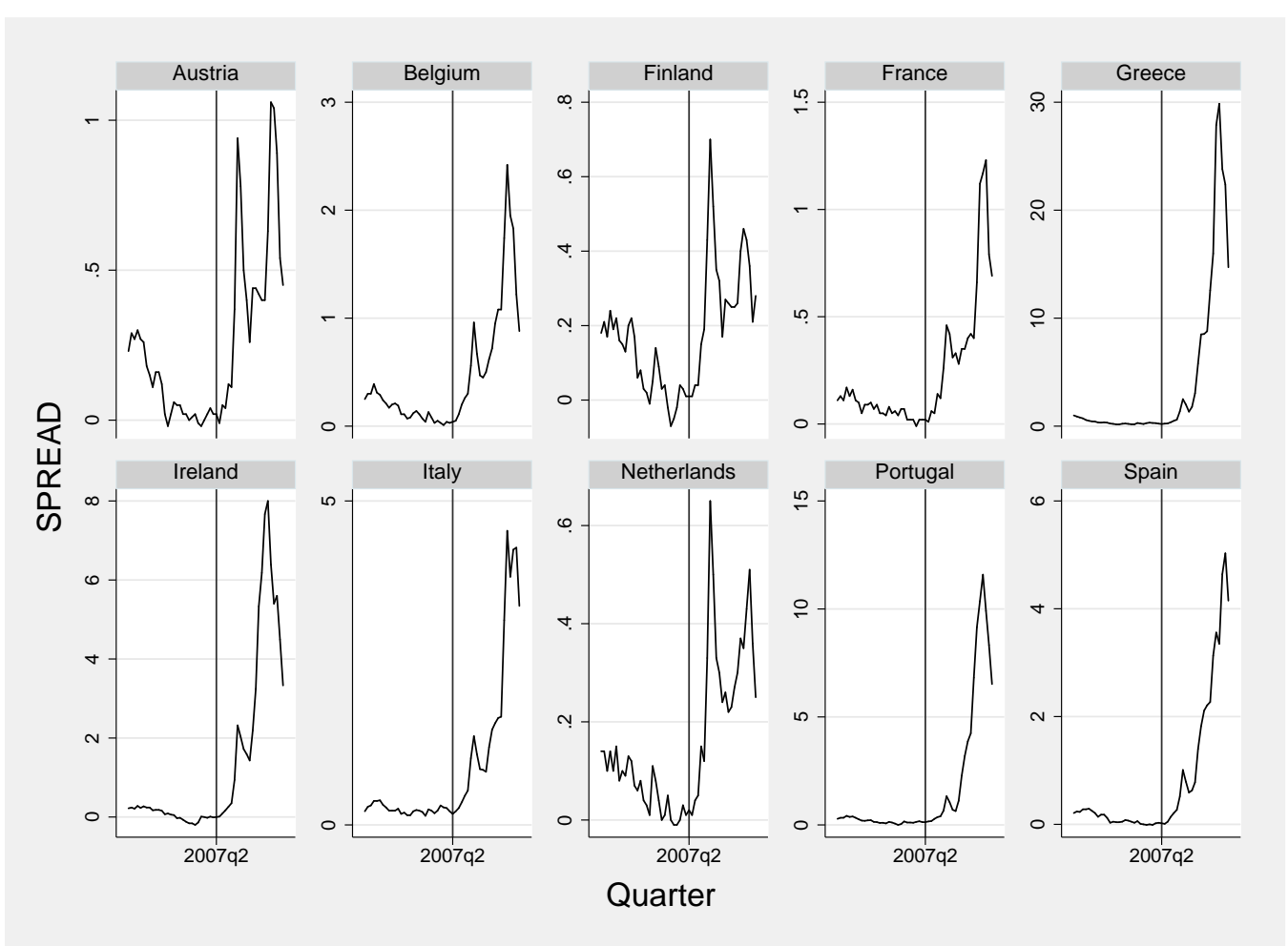

Source: own elaboration on Datastream dataset

diversification by the banks of each Core country towards the Periphery's financial assets. Large amounts of capitals of Core countries' banks, invested in the Core at the inception of the monetary union, moved to the financial markets of the Peripheral countries. Table 1 shows that the "lion's share" of portfolio investments in the Periphery was grasped by German and French banks, remarkably investing capitals in the Greek financial assets until 2007, and returning them back home during the crisis. The relative share of Periphery's over the overall Eurozone total owned by German banks rose from 1999 $(36 \%)$ to $2003(38 \%)$ to $2007(50 \%)$, eventually dropping to $39 \%$ in 2012, and the relative share owned by French banks rose from 1999 (41\%) to $2003(44 \%)$ to 2007 (56\%), eventually dropping to $38 \%$ in 2012. In absolute values (millions of US dollars, not reported in the 
Table), the sole investment in Greek financial assets by German banks rose from 27,673 in 2003 to 37,333 in 2007 , falling to 24,605 in 2012, while those in the hands of French banks rose from 9,924 in 2003 to 53,547 in 2007 and fell to 35,346 in 2012.

After the Lehmann collapse in September 2008, a drastic reversal in the market sentiment occurred worldwide. The period of negligible risk premia, started in 1999, was brought to an end by the transmission of a higher aversion to risk from the United States to Europe. In European financial markets the international risk factor interacted with worsening fiscal fundamentals (Attinasi et al., 2011). The financial crisis compelled governments to put public money into the European banks burdened by derivatives with declining market values. The financial support, or recapitalization funds, that banks received from governments not only caused a relevant rise in their public debt / GDP ratios, but also propelled a self-aggravating process. In fact, the decreasing value of Peripheral countries' sovereign bonds in portfolios of highly leveraged banks contributed to deteriorate their balance sheets of many Core countries' banks (von Hagen et al., 2011; Allen and Moessner, 2013) ${ }^{4}$. The more interconnected banks' portfolios were, the more a situation of illiquidity of a bank easily diffused within the network of banks, the faster insolvency conditions spread over (Tressel, 2010; Krause and Giansante, 2012). The probability of a sovereign debt default also appeared to be linked to short-term interest rates, a proxy related to the ability of a country to meet its obligations (Manganelli and Wolswijk, 2009; Longstaff et al., 2011).

The greater the size of the banking sector in a country, as measured by the aggregate balance sheet to GDP ratio, the higher the risk

\footnotetext{
${ }^{4}$ The liquidity risk is a proxy for the relative size of markets among the variables used in the literature in order to determine the spread as the probability that a limited depth of the sovereign bond market could provoke heavy capital losses in case of early liquidation,.. In this paper, we waive this variable, as it does not appear to play any substantial role in a majority of studies (Attinasi et al., 2011; Sgherri and Zoli, 2009; Barrios et al., 2009; Haugh et al., 2009; and Manganelli and Wolswijk, 2009). The likely reason is that the impact of liquidity risk on the spread is at least partly captured by the credit risk (Favero, Pagano, and von Tadden, 2010). Also measures of country risk and the agencies' rating of sovereign bonds were inserted in regression models, with mixed results (Attinasi et al., 2009; Arghyrou and Kontonikas, 2011). Since the spreads feed-back on these two variables, they cannot perform as independent variables contributing to the determination of the spread as the dependent variable (De Grauwe and Ji, 2012).
} 
Table 1: Cross-border financial integration within the Eurozone: Positions in Periphery's financial assets held by the banks of five Core countries (Percentage of the total of each Peripheral country, various years)

\begin{tabular}{|l|c|c|c|c|}
\hline & 1999 & 2003 & 2007 & 2012 \\
\hline Austria & $23 \%$ & $27 \%$ & $35 \%$ & $25 \%$ \\
Belgium & $26 \%$ & $33 \%$ & $31 \%$ & $36 \%$ \\
Finland & $20 \%$ & $15 \%$ & n.a. & n.a. \\
France & $41 \%$ & $44 \%$ & $50 \%$ & $38 \%$ \\
Germany & $36 \%$ & $38 \%$ & $79 \%$ & $39 \%$ \\
Netherlands & $30 \%$ & $34 \%$ & $39 \%$ & $22 \%$ \\
\hline Total Core & $\mathbf{3 4 \%}$ & $\mathbf{3 7 \%}$ & $\mathbf{4 6 \%}$ & $\mathbf{3 5 \%}$ \\
\hline
\end{tabular}

Table 2: Cross-border financial integration within the Eurozone: Positions in financial assets of six Core countries held by the Core's and by the Periphery's banks (percentage of the total of each Core country's financial assets, various years)

\begin{tabular}{|l|cc|cc|cc|cc|}
\hline & \multicolumn{2}{|c|}{1999} & \multicolumn{2}{c|}{2003} & \multicolumn{2}{c|}{2007} & \multicolumn{2}{c|}{2012} \\
\hline & core & peri & core & peri & core & peri & core & peri \\
\hline Austria & $90 \%$ & $10 \%$ & $94 \%$ & $6 \%$ & $53 \%$ & $47 \%$ & $50 \%$ & $50 \%$ \\
Belgium & $89 \%$ & $11 \%$ & $88 \%$ & $12 \%$ & $86 \%$ & $14 \%$ & $98 \%$ & $2 \%$ \\
Finland & $95 \%$ & $5 \%$ & $84 \%$ & $16 \%$ & $86 \%$ & $14 \%$ & $94 \%$ & $6 \%$ \\
France & $82 \%$ & $18 \%$ & $78 \%$ & $22 \%$ & $78 \%$ & $22 \%$ & $78 \%$ & $22 \%$ \\
Germany & $81 \%$ & $19 \%$ & $62 \%$ & $38 \%$ & $47 \%$ & $53 \%$ & $58 \%$ & $42 \%$ \\
Netherlands & $90 \%$ & $10 \%$ & $93 \%$ & $7 \%$ & $87 \%$ & $13 \%$ & $86 \%$ & $14 \%$ \\
\hline Total Core & $\mathbf{8 6 \%}$ & $\mathbf{1 4 \%}$ & $\mathbf{7 8 \%}$ & $\mathbf{2 2 \%}$ & $\mathbf{7 0 \%}$ & $\mathbf{3 0 \%}$ & $\mathbf{7 5 \%}$ & $\mathbf{2 5 \%}$ \\
\hline \multicolumn{8}{|c|}{ Source: own computation on BIS statistical Annexes } \\
\hline
\end{tabular}


that its public debt will soar as an effect of the government's rescue of distressed banks (Gerlach et al., 2010). The reciprocal distrust of banks resulted in the collapse of the Eurozone's inter-bank channel of financing and caused a "sudden stop" in capital inflows to Peripheral countries (Calvo, et al., 2008). Since the default risk premium on the Periphery's sovereign bonds rose, with the yields of the public debt in the Core remaining constant, a divide opened between the widening spreads of the less advanced Peripheral countries and those of the Core (Barrios et al., 2009). The forecasts by rating agencies and market operators corrected the weight for the loss of fiscal sustainability of Peripheral countries upwards (Sgherri and Zoli, 2009; Arghyrou and Kontonikas, 2010). In some high-debt Peripheral countries the rise in the spread appears to directly stem from the deterioration in fiscal positions, holding international risk aversion constant (Haugh et al., 2009). The interplay between rocketing public debt / GDP ratios, and the plummeting value of sovereign assets unfolding insolvency conditions across banks, caused the reversal of capital flows towards the Core banks and the Periphery' sovereign spreads vis-à-vis Germany widened (Caceres et al., 2010; Croci Angelini and Farina, 2012) ${ }^{5}$.

The larger the Core banks' fall in confidence in a Peripheral country's public debt, the more capital flows reverted to the "safe heaven" of the German and other Core financial markets (Panetta, 2011).

Table 2 documents the variation in the share of financial assets of Core countries respectively held by the banks of the Core and of the Peripheral countries. The portfolios of Peripheral banks remarkably widened as for the financial assets of Germany and France, and during the crisis also as for the Austrian financial assets.

A dramatic upward trend of sovereign spread was exhibited from 2008 to 2012 first by Ireland, followed by Greece and Portugal, and to a more limited extent by Spain and Italy, and eventually by the Core countries but Germany, too (see Figure 1). Ranked from min to max, - ranging from the minimum (0.65 points maximum spread in the Netherlands in 2009.1) to the maximum (around 3000 points in Greece in 2012.1) - in the third period all Core countries' spreads precede

${ }^{5}$ The lack of confidence among banks about mutual creditworthiness, negatively affected the liquidity transmission. A "sudden stop" due in the inter-bank refinancing channel brought about a credit crunch and many EMU countries exhibited a negative GDP growth in 2012. The fiscal sustainability of the "weak" member countries is also endangered by the absence of a mutual guarantee on sovereign bonds and of the assignment of the LoLR function to the ECB (De Grauwe and Ji, 2013). 
every Peripheral country's spreads. The fact that the confidence in the solvency of banks and governments abruptly fade away could be traced back to the institutional weaknesses of the Eurozone, which gave good reasons to financial markets for raising the risk premium after a major shock ${ }^{6}$.

The scatter diagrams in Figure 2 portray the estimated fitting line between the volatility of the international risk aversion (on the horizontal axis) - proxied by the S\&P index of the difference in yields between corporate bonds and Treasury securities of similar maturity ${ }^{7}$ - and the spread (on the vertical axis) in each EMU country. Once investors took accurate account of divergent macroeconomic performances within the Eurozone, the Core's and the Periphery's sovereign bonds yields entertain an idiosyncratic correlation with the evolution of market sentiment. While the value on the horizontal axis is common to all countries' diagrams, the spreads on the vertical axis widely differ between Core and Periphery. It is apparent that the Core countries exhibit a positive correlation, while for the Peripheral countries the correlation is nil.

The different market evaluation of the country-risk in the two areas of the Eurozone could have been influenced by the fact that the banking crisis and the fiscal crisis were strictly interwoven, as a consequence of the mutual exposure of banks and governments to the other party's insolvency risk. This liaison dangereuse could have been crucial to the formation of a higher country-risk for the Peripheral countries, so that their sovereign bonds' spreads rose much more than the spreads on the Core sovereign bonds. The extensive evidence of pronounced co-movements across Eurozone markets in 2008-09, mainly in the form of correlated increases in the yields of government bonds, should be taken as a necessary, although not sufficient, condition for the outbreak of a systemic risk ${ }^{8}$. The presence of a systemic risk in

\footnotetext{
${ }^{6}$ In the Eurozone, public bonds are still issued by member states without either a mutual risk insurance shielding countries from a recession or a common guarantee on debt redemption. Furthermore, the ECB does not have the function of lender of last resort (LoLR), its Statute forbids open market operations orientated to bailing-out a member country, so that governments are not in the position to guarantee that the cash will always be available to pay out bondholders at maturity (De Grauwe, 2011).

${ }^{7}$ As a proxy of international risk aversion we also used the United States stock market volatility index (VIX); the correlation with the Eurozone spreads is very similar.

${ }^{8}$ Systemic risk consists in the "probability that cumulative losses will accrue from an event that sets in motion a series of successive losses along a chain of institutions or
} 
Figure 2: Spreads and Volatility

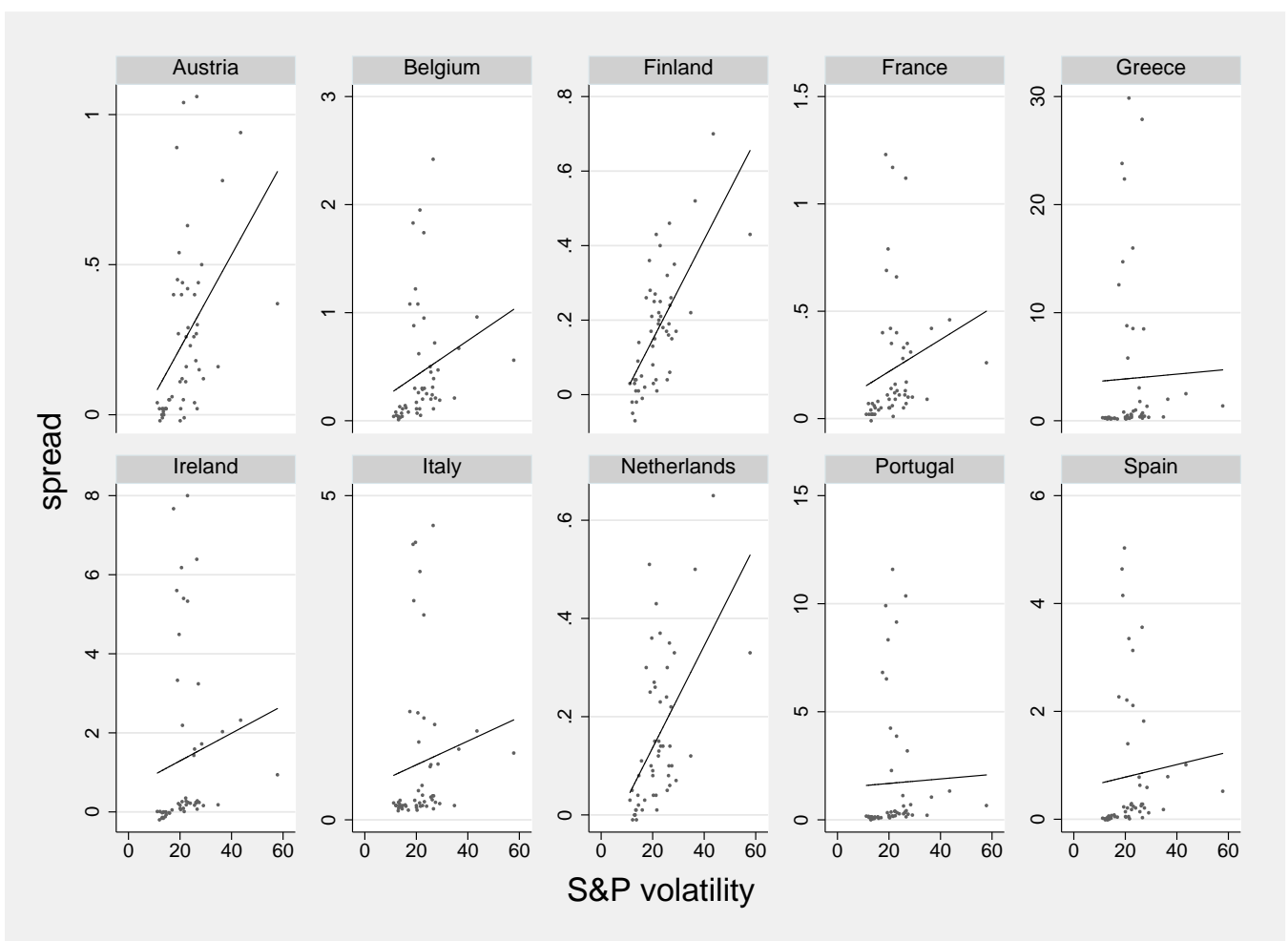

Source: own elaboration on Datastream dataset

a currency area, due to extensive cross-country linkages across financial markets, is typically detected after a large shock propagates as a contagion across markets (Forbes and Rigobon, 2002).

Also the efficiency divide between the Core and the Periphery productive systems has to be taken into account in dealing with the financial markets' appraisal of fiscal sustainability in Peripheral countries. After the launch of the Eurozone, the financial integration was expected to boost a faster catching-up in the per capita GDP growth rates of Peripheral backward economies. Many investors perceived the adoption of a single currency as a guarantee offered to the redemption of the Eurozone countries' public debt, also in the expectation that

markets comprising a system $(\ldots)$. That is, systemic risk is the risk of a chain reaction of falling interconnected dominos" (Kaufman, 1995, p. 47). 
a more sustained GDP growth would have improved public finances in high-public-debt countries and put on a declining path their public debt/GDP ratios. These premises were probably overstated. The hike in the growth rate enjoyed by countries such Ireland and Spain, where private investments largely exceeded private savings, were taken as the windfall gain stemming from financial integration, while they were mainly triggered by the moral hazard of speculative projects resulting in housing and financial bubbles (Giavazzi and Spaventa, 2010).

Similarly, the wide current account imbalances vis-à-vis the Core countries, which soon opened in Peripheral countries due to the huge rise of imported consumption goods, was viewed as a physiological consequence of the higher GDP growth, triggered by more abundant liquidity and much lower interest rates in countries with rates of inflation higher than the EMU average (Blanchard and Giavazzi, 2002). On the contrary, the main cause of the Peripheral countries' trade deficits was a declining competitiveness caused by upward trends of their unit labour cost (ULC) vis-à-vis the EMU-average, as a substantial reduction of their intra-EMU exports started just after 1999. The importance of the loss of the exchange rate policy instrument, previously often used by many Peripheral countries to counter a negative shock, was greatly underestimated. The plummeting degree of competitiveness hitting Peripheral countries contributed to the widening of the spreads (Belke and Dreger, 2011). A likely explanation is that an enduring fall in competitiveness is bound to reduce the growth rate. This makes the perspective fiscal solvency of a country deteriorate, both due to the functioning of automatic stabilizers, which raises public expenditures, and to the squeezing of fiscal revenues.

\section{A model of contagion across sovereign spreads}

Forbes and Rigobon (2002) proposed to define contagion across financial assets as a hike in cross-market correlation coefficients after a shock to one country (or group of countries). Since during crisis periods co-movements across markets are systematically observed, evidence of a contagion can be validated only after controlling for the upward bias in correlation coefficients due to market volatility. This analytical framework nicely applies to the evolution of sovereign spread across the Eurozone markets. Our model investigates whether 
a contagion propagated by separating out the role played by the market sentiment, as proxied by an index of volatility, from the possible influence of worsening macroeconomic fundamentals.

The developments above summarized suggest to interpret the Eurozone countries' sovereign spreads as highly interconnected due to a contagion across the risk of default of the member countries.

This interdependence among spreads has been recently proposed by means of GVAR (Global Vector Autoregressive) models which make each Eurozone country's spread dependent on others Eurozone countries spreads. Favero (2013) models interdependence among risk premia on sovereign bonds exclusively as a contagion operating through the time-varying "distance" between the Eurozone countries' fiscal fundamentals. The sole worsening in fiscal solvency after financial crisis is then taken responsible for mutually reinforcing increases in the spreads, signalling rising expectations of exchange rates' depreciation as an effect of one or more currencies exiting the Eurozone. The problem with this appraisal of the Eurozone's crisis is its lack of consideration for the channels through which the worsening solvency of governments transformed in varying expectations of default across countries, finally affecting their spreads.

The dynamic of spreads is modelled as a partial adjustment around a long run equilibrium level determined by market volatility, public debt/GDP ratio, competitiveness, and Global Spread.

Following Favero (2013), we use the following specification:

$$
\begin{gathered}
\Delta\left(Y_{t}^{i}-Y_{t}^{G}\right)=\beta_{i 0}+\beta_{i 1}\left(Y_{t-1}^{i}-Y_{t-1}^{G}\right)+\beta_{i 2} \Delta V O L_{t}+\beta_{i 3} V O L_{t-1} \\
+\beta_{i 4}\left(b_{t}^{i}-b_{t}^{G}\right)+\beta_{i 5}\left(\text { reer }_{t}^{i}-\text { reer }_{t}^{G}\right) \\
+\beta_{i 6}\left(Y_{t-1}^{i}-Y_{t-1}^{G}\right)^{E, b}+u_{i t} \\
\left(Y_{t}^{i}-Y_{t}^{G}\right)^{E, b}=\sum_{j \neq i} w_{j i}^{k}\left(Y_{t}^{i}-Y_{t}^{G}\right) \\
w_{j i}^{k}=\frac{w_{j i}^{*}}{\sum_{j \neq i} w_{j i}^{*}}, w_{j i}^{*}=\frac{1}{d i s t_{j, i}^{b}} \\
d i s t_{j i}^{b}=\frac{\left|b_{t}^{j}-b_{t}^{i}\right|}{60}
\end{gathered}
$$

where 
- $Y_{t}^{i}-Y_{t}^{G}$ : spread between government bonds of country $i$ and Germany government bonds;

- $V O L$ : volatility, $\mathrm{S} \& \mathrm{P}$ index of the difference in yields between corporate bonds and Treasury securities of similar maturity;

- $b_{t}^{i}$ : debt to GDP ratio;

- $\operatorname{reer}_{t}^{i}$ : Real Effective Exchange Rate

- $\left(Y_{t}^{i}-Y_{t}^{G}\right)^{E, b}=$ this term consist in a Global Variable designed to capture a time-varying interdependence among spreads in the euro area. This variable define for each country global spreads which are weighted average of other countries spreads where weights depend on the distance, measured in terms of differences in debt to GDP ratio $\left(b_{t}^{i}\right)$, that separates Euro countries;

- $i=1, \ldots, 10$ identifies the ten countries, while $t$ indicates the time, and $u$ the error term.

We collected quarterly data from Datastream and our analysis refers to the initial EMU membership plus Greece, except Luxembourg.

The S\&P Index of US stock volatility ( VOL) is a proxy for the "market sentiment". Our hypothesis is that the boost to financial integration created a network of European banks very interconnected through the diversification in Peripheral countries' sovereign bonds. The excessive interconnection between banks of some countries and sovereign bonds of other countries exposed the Eurozone to systemic risk. We analyze whether, after the emergence of fiscal and competitiveness distresses of Periphery countries, the worsening of market sentiment affect yield spreads (of Core countries, in particular). Once the perception of a systemic risk builds up, the complex network connecting European banks could easily spread the fear of sovereign bonds' insolvency over EU countries, independently of their individual macroeconomic conditions. Moreover, the government debt to be used as collateral was devalued. When uncertainty soars in worldwide financial markets, investors drastically change their sentiment about the European countries also because the public bonds they issue are denominated in a currency over which they have no control, so that their governments are not in a position to guarantee that the cash will always be available to pay out bondholders at maturity. Furthermore, financial operators take into account that the ECB is unable to act as a LoLR, and is also constrained by the no-bail-out clause dictated by 
its Statute. These institutional weaknesses of the EMU indicate that the confidence in the solvency of banks and governments can abruptly fade away, thus giving good reasons to financial markets for raising the risk premium.

The public debt/GDP ratio and the real effective exchange rate (REER) are the two variables conveying the influence of each country's macroeconomic fundamentals on the propagation of the rise in the risk premium on sovereign bonds. The path followed by the public debt/GDP ratio represents the market evaluation of fiscal sustainability of the country, that is the "credit risk", the creditworthiness of the country's perspective public finances ${ }^{9}$.

Econometric evidence presented by Barrios et al. (2009) also shows that in the presence of high risk aversion the spread for high public debt countries always soars, independently of the government's efforts in fiscal retrenchment. In fact, the solo planning of surpluses in the public budget of future periods could not be enough to reassure financial operators.

As to the other macroeconomic fundamental, a country's REER path deviating from the path followed by its most proximate market competitors signals a competitiveness loss conveyed by real appreciation $^{10}$. A wage rate dynamics increasingly exceeding the labour productivity dynamics warns of a likely reduction in net exports. If a country suffers from a severe loss of competitiveness, so that the reversal of the current account imbalance is in doubt, and if foreign investors are no longer willing to invest in the country and the residents are unable to sell their foreign assets, banks' liabilities and/or public debt will increase.

A market adjustment is then needed through a reduction of prices and wages in the high-public-debt countries, but market operators could be afraid of a prolonged deflation negatively impinging upon the fiscal revenues needed for the fiscal retrenchment. Hence, the steeper the rising path followed by the REER, the larger will be the

\footnotetext{
${ }^{9}$ For the reasons exposed in the previous section, we decided to waive the "liquidity risk" and focus on the "credit risk".

${ }^{10}$ The tight connections between the REER and the current account suggest verifying whether our estimates would improve by considering this latter variable too, which not only reflects competitiveness but also the influence of the level of domestic demand on the country's imports. The replacement of the REER with the current account is not satisfactory, as this variable turns out to be less significant than the REER. In addition, when both variables are included the current account coefficient becomes insignificant.
} 
risk premium imposed by financial markets.

As stated before, the increasing financial integration makes necessary to consider the exposure of each country's spread to the other spreads in the euro area. Our Global Spread variable is built up by a weighted average of the yield spreads in EU countries. The weights are time-varying, related to changes of fiscal fundamentals, and make global spread more dependent on the spreads of those countries that are more similar in terms of fiscal fundamentals. The global variables is included through their lags. Including the contemporaneous global variables would be problematic, because these variables are unlikely to be exogenous (Pesaran et al., 2004). In our model, the conditions for exogeneity are likely to be violated, and the contemporaneous global spreads will be endogenous for the estimation of the parameters.

Estimation of the GVAR panel model is implemented by a GLS panel, including country fixed effects. The method allows for heteroskedastic and correlated error structure and, furthermore, uses a panel-specific ar(1) autocorrelation structure. We made these choices after the appropriate tests.

\section{Results}

Table 3 shows the effects on spreads of market sentiments (volatility), fiscal fundamentals (public debt), competitiveness (reer) and Global Spreads. The model has been estimated over the euro regime for the sample 2000m1-2012m6, and includes the subprime crisis. Table 4 reports the same analysis, by separating months characterized by "high" spreads (average monthly spread over the median value of the period 2000-2012), by periods of "low" spreads (average monthly spread under the median value).

In table 3, the Periphery (1) estimate shows that the (high) spread of periphery countries actually depend on fiscal fundamentals and competitiveness, and do not depend on market sentiments. Core estimations (1) and (2) highlight that, in the period 2000-2012, the spreads of Core countries have been negatively influenced by market

sentiments, while they were by no means affected by competitiveness and fiscal fundamentals.

The rise in the volatility was reflected by the Core countries' spreads only during the period of high spreads prompting the "flight to qual- 
Table 3: Spreads on Bunds, monthly data, 2000m1-2012m6

\begin{tabular}{c|c|c|c|} 
& $\begin{array}{c}\text { panel } \\
\text { all countries }\end{array}$ & $\begin{array}{c}\text { panel } \\
\text { core }\end{array}$ & $\begin{array}{c}\text { panel } \\
\text { periphery }\end{array}$ \\
\hline$\left(Y_{t-1}^{i}-Y_{t-1}^{G}\right)$ & $0.019^{* * *}$ & $-0.073^{* * *}$ & $0.020^{* *}$ \\
& $(0.007)$ & $(0.016)$ & $(0.009)$ \\
\hline$V O L_{t-1}$ & 0.001 & $0.001^{* * *}$ & 0.001 \\
& $(0.001)$ & $(0.000)$ & $(0.001)$ \\
\hline$\Delta V O L_{t}$ & $0.001^{*}$ & $0.002^{* *}$ & $0.010^{* * *}$ \\
& $(0.001)$ & $(0.001)$ & $(0.003)$ \\
\hline$\left(b_{t}^{i}-b_{t}^{G}\right)$ & $0.001^{* *}$ & 0.000 & $0.004^{* *}$ \\
& $(0.001)$ & $(0.000)$ & $(0.002)$ \\
\hline$\left(\right.$ reer $_{t}^{i}-$ reer $\left._{t}^{G}\right)$ & $0.002^{* *}$ & 0.000 & $0.006^{* * *}$ \\
& $(0.001)$ & $(0.001)$ & $(0.002)$ \\
\hline$\left(Y_{t-1}^{i}-Y_{t-1}^{G}\right)^{E, b}$ & -0.005 & $0.016^{* * *}$ & $-0.023^{* * *}$ \\
\hline Wald $\chi^{2}$ & $(0.003)$ & $(0.004)$ & $(0.008)$ \\
\hline$p>\chi^{2}$ & 51.57 & 34.90 & 64.65 \\
\hline $\mathrm{n}$ & 0.000 & 0.000 & 0.000 \\
\hline & 1390 & 695 & 695 \\
\hline
\end{tabular}

Notes: Robust standard errors in parentheses

${ }^{*} p<0.1 ;{ }^{* *} p<0.05 ;{ }^{* * *} p<0.01$

Country fixed effects

ity", thus indicating that the contagion consists in the fact that has essentially been triggered by the perception of a growing systemic risk.

While the spreads of Core Countries are affected by systemic risk and do not depend on fiscal fundamentals $(b)$ and competitiveness (reer), growing volatility seems to not hit the spreads of Periphery Countries. On the contrary, the Periphery spreads increased as an effect of the worsening of public debt/GDP ratios and of the REER as the indicator of competitiveness (both in the high and the low volatility periods, as stated by table 4 .

In presence of an increasing of spreads, both of Periphery Countries because of $b$ and reer trends, and of Core Countries because of increasing volatility ( $V O L$, contagion), the Global Spread variable raises for all countries.

The results about the increasing of Global Spread presented in Table 3 deserve a deepening, because it seems to have positive (not significant) consequences over spreads (it determines lower spreads) in first column's estimates. As the Global Spread widens, the spread 
Table 4: Spreads on Bunds, monthly data, 2000m1-2012m6

\begin{tabular}{c|c|c|c|c|c|c|} 
& $\begin{array}{c}\text { panel } \\
\text { all countries } \\
\text { low spreads }\end{array}$ & $\begin{array}{c}\text { panel } \\
\text { all countries } \\
\text { high spreads }\end{array}$ & $\begin{array}{c}\text { panel } \\
\text { core } \\
\text { low spreads }\end{array}$ & $\begin{array}{c}\text { panel } \\
\text { core } \\
\text { high spreads }\end{array}$ & $\begin{array}{c}\text { panel } \\
\text { periphery } \\
\text { low spreads }\end{array}$ & $\begin{array}{c}\text { panel } \\
\text { periphery } \\
\text { high spreads }\end{array}$ \\
\hline$\left(Y_{t-1}^{i}-Y_{t-1}^{G}\right)$ & $-0.241^{* * *}$ & 0.001 & $-0.268^{* * *}$ & $-0.097^{* * *}$ & $-0.243^{* * *}$ & -0.000 \\
& $(0.023)$ & $(0.011)$ & $(0.036)$ & $(0.026)$ & $(0.034)$ & $(0.015)$ \\
\hline$V O L_{t-1}$ & 0.000 & 0.000 & $0.001^{*}$ & $0.003^{* * *}$ & 0.000 & -0.001 \\
& $(0.000)$ & $(0.001)$ & $(0.000)$ & $(0.001)$ & $(0.000)$ & $(0.003)$ \\
\hline$\Delta V O L_{t}$ & 0.000 & $0.003^{* *}$ & 0.000 & $0.003^{* *}$ & $0.001^{*}$ & $0.011^{* * *}$ \\
& $(0.000)$ & $(0.001)$ & $(0.001)$ & $(0.001)$ & $(0.000)$ & $(0.004)$ \\
\hline$\left(b_{t}^{i}-b_{t}^{G}\right)$ & $0.0004^{* *}$ & $0.002^{* *}$ & $0.001^{*}$ & 0.000 & 0.001 & $0.008^{* *}$ \\
& $(0.000)$ & $(0.001)$ & $(0.000)$ & $(0.001)$ & $(0.000)$ & $(0.003)$ \\
\hline$\left(r e e r_{t}^{i}-r e e r_{t}^{G}\right)$ & $0.0004^{*}$ & $0.003^{*}$ & 0.000 & 0.000 & $0.001^{*}$ & $0.012^{* * *}$ \\
& $(0.000)$ & $(0.002)$ & $(0.000)$ & $(0.001)$ & $(0.000)$ & $(0.004)$ \\
\hline$\left(Y_{t-1}^{i}-Y_{t-1}^{G}\right)^{E, b}$ & $0.088^{* * *}$ & -0.004 & 0.028 & $0.021^{* * *}$ & $0.128^{* * *}$ & $-0.032^{* *}$ \\
& $(0.023)$ & $(0.006)$ & $(0.038)$ & $(0.007)$ & $(0.037)$ & $(0.014)$ \\
\hline Wald $\chi^{2}$ & 116.03 & 41.84 & 60.33 & 26.58 & 57.76 & 47.39 \\
\hline$p>\chi^{2}$ & 0.000 & 0.000 & 0.002 & 0.000 & 0.000 & 0.000 \\
\hline n & 740 & 650 & 370 & 325 & 125 & 325 \\
\hline Notes: Robust standard errors in parentheses & & & & \\
${ }^{*} p<0.1 ;{ }^{* *} p<0.05 ;{ }^{* * *} p<0.01$ & & & & &
\end{tabular}

in the estimates of the first column of Table 3 reduces. Yet, an increase of the Global Spread causes opposite effects on spreads if Core or Periphery are separately considered, as shown by the Core and Periphery estimates. Core countries seem to suffer negative effects from the global movements of spreads in EU area, while Periphery countries even benefit from it.

Table 5 presents estimates for two different periods: before and after the second quarter of 2007, taken as the beginning of crisis end raising spreads (Figure 1). Until the beginning of the crisis, spreads are stables. From the middle of 2007, spreads of Periphery countries rise because of higher debt to GDP ratio and lower competitiveness, while spreads of Core countries suffer the worsening of market sentiments (VOL, systemic risk). The positive relation between the $\mathrm{S} \& \mathrm{P}$ index of volatility and spreads of Core countries, in presence of a worsening in competitiveness and fiscal fundamentals of Periphery countries, is an evidence of a contagion driven by shifts in market sentiment. The grow of spreads turns out in an increase of Global Spread variable for all countries, with opposite consequences on Periphery and Core, 
because it generates expectations of institutional actions (i.e. help for periphery countries) with opposite consequences for government budgets of Periphery and Core countries, as discussed above.

\section{Concluding remarks}

Data drawn from banks' portfolios show that the launch of the monetary union prompted a rapid financial integration, which resulted in excess exposure of Core countries' banks in the Periphery's financial assets. Empirical evidence indicates that almost flat paths of sovereign bonds' yields were upward moved by the financial crisis, with the Periphery's sovereign bonds exhibiting disproportionate increases of sovereign bonds' spreads with respect to the 10 year German Bund.. The contribution of this paper to the literature on the crisis of the Eurozone consists in the application of the GVAR methodology to detect a contagion effect within the Eurozone. Estimates conducted by our GVAR model, where each country's spread depends upon all Eurozone countries' spreads, indicate that the huge rise in the sovereign yields of Peripheral countries is correlated to their macroeconomic fundamentals, namely the public debt/GDP ratio and REER values increasing with respect to the Eurozone average index, whereas the rise in the Core countries' spreads was initially determined by the rising international risk aversion. The fall in the solvency conditions of the Periphery's public debt not only created the upward trend in those countries' spreads but also magnified the impact of the deteriorating market sentiment on the Core' sovereign bonds, negatively impinging on their spreads as well. The rise of the Core spreads can be traced back to mounting expectations in the markets of an enduring financial instability within the Eurozone, associated with possible defaults in the Periphery.

\section{References}

Allen, W. A. and Moessner, R. (2013) The liquidity consequences of the euro area sovereign debt crisis, BIS Working Papers, No. 390.

Arghyrou, M.G. and Kontonikas, A. (2011) "The EMU sovereign-debt crisis: Fundamentals, expectations and contagion", European Econ- 
Table 5: Spreads on Bunds, monthly data, 2000m1-2012m6

\begin{tabular}{c|c|c|c|c|} 
& $\begin{array}{c}\text { panel } \\
\text { core } \\
2000 \mathrm{~m} 1-2007 \mathrm{~m} 4\end{array}$ & $\begin{array}{c}\text { panel } \\
\text { core } \\
2007 \mathrm{~m} 5-2012 \mathrm{~m} 6\end{array}$ & $\begin{array}{c}\text { panel } \\
\text { periphery } \\
2000 \mathrm{~m} 1-2007 \mathrm{~m} 4\end{array}$ & $\begin{array}{c}\text { panel } \\
\text { periphery } \\
2007 \mathrm{~m} 5-2012 \mathrm{~m} 6\end{array}$ \\
\hline$\left(Y_{t-1}^{i}-Y_{t-1}^{G}\right)$ & $-0.220^{* * *}$ & $-0.096^{* * *}$ & $-0.155^{* * *}$ & -0.030 \\
& $(0.032)$ & $(0.027)$ & $(0.024)$ & $(0.020)$ \\
\hline$V O L_{t-1}$ & 0.000 & $0.003^{* * *}$ & 0.000 & 0.001 \\
& $(0.000)$ & $(0.001)$ & $(0.000)$ & $(0.003)$ \\
\hline$\Delta V O L_{t}$ & 0.000 & $0.003^{* *}$ & 0.001 & $0.012^{* *}$ \\
& $(0.001)$ & $(0.001)$ & $(0.001)$ & $(0.005)$ \\
\hline$\left(b_{t}^{i}-b_{t}^{G}\right)$ & $0.001^{* * *}$ & 0.001 & $0.001^{*}$ & $0.021^{* * *}$ \\
& $(0.000)$ & $(0.001)$ & $(0.000)$ & $(0.006)$ \\
\hline$\left(\right.$ reer $_{t}^{i}-$ reer & 0.000 & 0.000 & 0.000 & $0.028^{* * *}$ \\
\hline$\left(Y_{t-1}^{i}-Y_{t-1}^{G}\right)^{E, b}$ & $(0.000)$ & $(0.002)$ & $(0.000)$ & $(0.007)$ \\
\hline Wald $\chi^{2}$ & $0.076^{* * *}$ & $0.017^{* *}$ & $0.079^{* *}$ & $-0.024^{*}$ \\
\hline$p>\chi^{2}$ & $(0.028)$ & $(0.007)$ & $(0.031)$ & $(0.013)$ \\
\hline $\mathrm{n}$ & 51.43 & 25.55 & 50.73 & 52.03 \\
\hline & 0.000 & 0.008 & 0.002 & 0.000 \\
\hline
\end{tabular}

Notes: Robust standard errors in parentheses

${ }^{*} p<0.1 ;{ }^{* *} p<0.05 ;{ }^{* * *} p<0.01$

Country fixed effects 
omy, European Commission, Economic Papers No. 436.

Attinasi, M., Checherita, C., and Nickel, C. (2011) What explains the surge in Euro area sovereign spreads during the financial crisis of 2007-2009?, in Robert W. Kolb (ed.), Sovereign Debt. From Safety to Default, New York, John Wiley \& Sons, Inc.

Balli, F., Basher, S.A., and Ozer-Balli, H. (2010) From home bias to Euro bias: Disentangling the effects of monetary union on the European financial markets, Journal of Economics and Business, 62, pp.347-366.

Barrios, S., Iversen, P., Lewandowska, M., and Setzer, R. (2009) "Determinants of intra-euro area government bond spreads during the financial crisis", European Economy, European Commission, Economic Papers No. 388.

Belke, A. and Dreger, C. (2011) Current account imbalances in the euro area: Catching up or competitiveness?, European University Viadrina Frankfurt (Oder), Department of Business Administration and Economics Discussion Paper No. 297.

Blanchard, O. and Giavazzi, F. (2002) "Current Account Deficits in the Euro Area: The End of the Feldstein-Horioka Puzzle?", Brookings Papers on Economic Activity, 2:, pp.147-186.

Caceres, C., Guzzo, V. and Segoviano, M. (2010) "Sovereign Spreads: Global Risk Aversion, Contagion or Fundamentals?", IMF Working Paper No.120.

Calvo, G. A., Izquierdo, A., and Mejía, L.-F. (2008) "Systemic Sudden Stops: The Relevance of Balance-Sheet Effects and Financial Integration", Inter-American Development Bank, Research Department, Working Paper No.637.

Croci Angelini E. and Farina, F. (2012) "Current Account Imbalances and Systemic Risk in a Monetary Union", in Journal of Economic Behavior and Organization, 83 (3), pp. 647-656.

Codogno, Lorenzo, Favero, C., Missale, A., (2003).Yield spreads on 
EMU government bonds. Economic Policy 18 (37), 503-532.

De Grauwe, P (2011) The Governance of a Fragile Eurozone, CEPS Working Documents.

De Grauwe, P e Ji, Y. (2012) "Mispricing of Sovereign Risk and Macroeconomic Stability in the Eurozone", in Journal of Common Market Studies, 50 (6): 866-880.

De Grauwe, P e Ji, Y. (2013) "Self-fulfilling crises in the Eurozone: an empirical test", Journal of International Money and Finance, 34: $15-36$.

Favero C.A. (2013) "Modelling and forecasting government bond spreads in the euro area: A GVAR model", Journal of Econometrics, 177: 34356.

Favero, C.A., Pagano, M., and von Thadden, E-L. (2010) "How does liquidity affect government bond yields?", Journal of Financial and Quantitative Analysis, 45: 107-34.

Forbes, K. J. and Rigobon, R. (2002), "No contagion, only interdependence: measuring stock market co-movement", Journal of Finance, 57, (5), pp. 2223-2261.

Gerlach, S., Schulz, A. and Wolff, G. B. (2010) "Banking and sovereign risk in the Euro Area", CEPR Discussion paper, No. 7833.

Giavazzi, F. and Spaventa, L. (2010) "Why the Current Account May Matter in a Monetary Union - Lessons from the Financial Crisis in the Euro Area", CEPR Discussion paper, No. 8008.

Greenwald B. and J. Stiglitz (1986) "Externalities in Economies with Imperfect Information and Incomplete Markets", The Quarterly Journal of Economics, 101(2): 229-64.

Haugh, D., Ollivaud, P. and Turner, D. (2009) "What drives sovereign risk premiums? An analysis of recent evidence from the Euro Area", OECD Economic Department Working Papers, No. 718. 
Kaufman, G.G. (1995) "Comment on Systemic Risk", in G.G. Kaufman (ed.) Research in Financial Services: Banking, Financial Markets, and Systemic Risk, vol. 7, pp. 47-52.

Krause, A. and Giansante, S. (2012) "Interbank lending and the spread of bank failures: A network model of systemic risk", Journal of Economic Behavior and Organization, 83 (3), pp.583-608.

Jappelli, T. and Pagano, M. (2010) "Financial Market Integration under EMU", in M.Buti, S.Deroose, V.Gaspar, J. Nogueira Martins (eds.), The Euro: The First Decade, Cambridge, Cambridge University Press.

Lane, P. R. and Milesi-Ferretti, G.M. (2012) "External adjustment and the global crisis," Journal of International Economics, 88, pp. 252-265.

Longstaff, F. A., Pan, J., Pedersen, L. H., and Singleton, K. J. (2011) "How Sovereign Is Sovereign Credit Risk?", American Economic Journal: Macroeconomics , 3: 75-103.

Manganelli, S. and Wolswijk, G. (2009) "What drives spreads in the euro area government bond market?," Economic Policy, 24, pp.191240.

Panetta, F. (2011) "The impact of sovereign credit risk on bank funding conditions", CGFS Papers No 43.

Pesaran, M.H., Schuermann, T., Weiner, S.M., (2004). Modelling regional interdependencies using a global error-correcting macro-econometric model. Journal of Business and Economic Statistics 22 (2), 129-162.

Schmitz, B. and von Hagen, J. (2010) "Current account imbalances and financial integration in the euro area", Journal of International Money and Finance, 30, pp. 1676-95.

Sgherri, S., and Zoli, E. (2009) "Euro Area Sovereign Risk During the Crisis," IMF Working Paper, No. 222.

Stiglitz J. (2010) "Contagion, Liberalization, and the Optimal Structure of Globalization", Journal of Globalization and Development, 
Vol. 1 (2): 1-45.

Tressel, T. (2010) Financial Contagion through Bank Deleveraging: Stylized Facts and Simulations Applied to the Financial Crisis, IMF Working Paper No.236.

von Hagen, J., Schuknecht, L., and Wolswijk, G. (2011) "Government bond risk premiums in the EU revised: The impact of the financial crisis" European Journal of Political Economy, 27: 36-43.

Waysand, C., Ross, K., and de Guzman, J. (2010) European Financial Linkages: A New Look at Imbalances, IMF Working Paper No.295. 